\title{
Vegetation Resilience under Increasing Drought Conditions in Northern Tanzania
}

\author{
Steye L. Verhoeve ${ }^{1, * \mathbb{C}}$, Tamara Keijzer ${ }^{2}$, Rehema Kaitila ${ }^{3}$, Juma Wickama ${ }^{4}$ and Geert Sterk ${ }^{1}$ \\ 1 Faculty of Geosciences, Utrecht University, Princetonlaan 8A, 3584 CB Utrecht, The Netherlands; \\ g.sterk@uu.nl \\ 2 PBL Netherlands Environmental Assessment Agency, Bezuidenhoutseweg 30, 2594 AV The Hague, \\ The Netherlands; tamara.keijzer@pbl.nl \\ 3 Tanzania National Parks, Lake Manyara National Park, Arusha P.O. Box 3134, Tanzania; \\ rehema.kaitila@tanzaniaparks.go.tz \\ 4 Tanzania Agricultural Research Institution, Mlingano, Tanga P.O. Box 5088, Tanzania; wickama@yahoo.com \\ * Correspondence: s.l.verhoeve@uu.nl
}

check for updates

Citation: Verhoeve, S.L.; Keijzer, T.; Kaitila, R.; Wickama, J.; Sterk, G. Vegetation Resilience under Increasing Drought Conditions in Northern Tanzania. Remote Sens. 2021, 13, 4592. https://doi.org/10.3390/ rs13224592

Academic Editor: Elias Symeonakis

Received: 14 September 2021

Accepted: 22 October 2021

Published: 15 November 2021

Publisher's Note: MDPI stays neutral with regard to jurisdictional claims in published maps and institutional affiliations.

Copyright: (c) 2021 by the authors. Licensee MDPI, Basel, Switzerland. This article is an open access article distributed under the terms and conditions of the Creative Commons Attribution (CC BY) license (https:// creativecommons.org/licenses/by/ $4.0 /)$.
Abstract: East Africa is comprised of many semi-arid lands that are characterized by insufficient rainfall and the frequent occurrence of droughts. Drought, overgrazing and other impacts due to human activity may cause a decline in vegetation cover, which may result in land degradation. This study aimed to assess drought occurrence, vegetation cover changes and vegetation resilience in the Monduli and Longido districts in northern Tanzania. Satellite-derived data of rainfall, temperature and vegetation cover were used. Monthly precipitation (CenTrends v1.0 extended with CHIRPS2.0) and monthly mean temperatures (CRU TS4.03) were collected for the period of 1940-2020. Eight-day maximum value composite data of the normalized difference vegetation index (NDVI) (NOAA CDR-AVHRR) were obtained for the period of 1981-2020. Based on the meteorological data, trends in rainfall, temperature and drought were determined. The NDVI data were used to determine changes in vegetation cover and vegetation resilience related to the occurrence of drought. Rainfall did not significantly change over the period of 1940-2020, but mean monthly temperatures increased by $1.06{ }^{\circ} \mathrm{C}$. The higher temperatures resulted in more frequent and prolonged droughts due to higher potential evapotranspiration rates. Vegetation cover declined by $9.7 \%$ between 1981 and 2020, which is lower than reported in several other studies, and most likely caused by the enhanced droughts. Vegetation resilience on the other hand is still high, meaning that a dry season or year resulted in lower vegetation cover, but a quick recovery was observed during the next normal or above-normal rainy season. It is concluded that despite the overall decline in vegetation cover, the changes have not been as dramatic as earlier reported, and that vegetation resilience is good in the study area. However, climate change predictions for the area suggest the occurrence of more droughts, which might lead to further vegetation cover decline and possibly a shift in vegetation species to more drought-prone species.

Keywords: drought impacts; NDVI; drought adaptation; drought index; vegetation resilience; drought vulnerability; standardized precipitation evapotranspiration index; AVHRR; land degradation

\section{Introduction}

The main component of terrestrial ecosystems is vegetation, which has a direct link to many ecosystem services, such as food production, soil retention, climate regulation, water purification and disease management [1]. The value of these services could decline or disappear with an increasing pressure on vegetation resources. Not only natural influences such as wildlife grazing and the weather, but anthropogenic pressures can also have a negative influence on the productivity of vegetation [2].

Land degradation is defined as changes in land use from productive to unproductive due to natural or human-made factors [3]. Land degradation is one of the world's 
major socio-economic and environmental problems, affecting two-fifths of humanity [4]. Agricultural expansion has led to severe land degradation all over the world, particularly when accompanied by high water consumption and the conversion of natural landscapes into cultivated lands [5-7]. Land degradation undermines the land's productivity and contributes to the degradation of ecosystem services. Land degradation disproportionately affects the poor and is sometimes the decisive component that causes poverty and social conflict $[8,9]$. The loss of productive land is part of a vicious circle for many rural people in developing countries in which land degradation can be both the cause and the effect of poverty [10].

Semi-arid ecosystems in particular are under pressure from the rising demand for natural resources and an increase in weather extremes. This is caused by an increasing human population and by climate change, respectively. More frequent and severe droughts have been forecasted in the 21st century, particularly in the mid-latitudes [11]. Increases in drought occurrences are driven by a decrease in precipitation and/or an increase in evapotranspiration due to higher daily temperatures [12]. As water availability acts as the main driver of vegetation distribution and productivity in arid and semi-arid regions [13], droughts impose a serious risk on the livelihood of many people [14].

Previous studies show that Eastern Africa has been suffering from an increase in temperature and more frequent droughts, which have continued in the 21st century [15]. In this region a browning trend of the vegetation has occurred in the past 40 years [16,17], which is among the most notable vegetation browning in the world. Some reports also show a decline in vegetation productivity and an increase in land degradation $[1,3,18]$. On the other hand, other remote-sensing-based studies have shown that areas in East Africa have experienced fluctuations in vegetation cover, which were largely driven by variations in soil moisture [19]. This can be explained by the quick response of vegetation in arid and semi-arid biomes to rainfall fluctuations. Plant species have adopted mechanisms that allow them to rapidly adapt to changing water availability and are also able to withstand water deficits [20]. These mechanisms suggest a strong revival of vegetation health during periods of water abundance [21]. However, the way vegetation responds to drought on different time scales remains largely unknown because of the different response times and vulnerability that species have to drought. By knowing this, the severity of degradation can be assessed, and an estimate can be made on the importance of applying measures.

The semi-arid zone in northern Tanzania is an example of an area that suffers from increasing droughts and enhanced soil degradation [22]. The area close to Lake Manyara, covered by the Monduli and Longido districts, is primarily comprised of savanna and rangeland, which is widely used for livestock grazing by the local Masai herders. According to Wynants et al. [23], 2.0\% of this area is degraded while there has been a serious increase in the soil erosion risk from 1988 to 2016. Masai herders in the area complain about more frequent droughts and a lack of sufficient grazing resources. Part of the problem faced by the Masai is an increase in livestock numbers, which results in more pressure on grazing resources $[18,24,25]$. Using Landsat satellite imagery from the Google Earth Engine, Verhoeve [24] studied land use/cover changes in the Monduli and Longido districts over the period of 1985-2018. The results showed widely fluctuating land use/cover classes over time, and neither revealed any significant changes in land cover nor provided evidence for large-scale vegetation degradation. These results contradict previous studies that showed overall degrading vegetation cover in the study area $[17,23,25,26]$. According to Verhoeve [24], vegetation cover is largely influenced by the amount of precipitation and the occurrence of drought. However, it was also clear that vegetation resilience in the study area is high, with a good recovery of vegetation cover following a drought year. Similar observations were made for Sahelian West Africa, where the vegetation recovered following the devastating droughts of the late 1970s and early 1980s [21].

In this study we used satellite-derived hydrometeorological data for drought analysis and the normalized difference vegetation index (NDVI) as a proxy for vegetation response to drought. The main objective was to investigate the resilience of vegetation to drought 
over different time scales in northern Tanzania during 1981-2020. To achieve this objective, we first investigated the long-term hydrometeorological data and the occurrence of drought in the region. Next, we analyzed the long-term interannual NDVI trends in the region. Finally, we determined the short-term effects of drought on vegetation health and recovery at different time periods.

\section{Materials and Methods}

\subsection{Study Area}

The study area comprises the districts of Monduli and Longido in Arusha Region, northern Tanzania (Figure 1) [25,27]. The total area covers approximately $16,000 \mathrm{~km}^{2}$ and has some 282,000 inhabitants [28]. The majority of the area lies in the East African Rift Valley and is bordered by a high ( 1300 $\mathrm{m}$ a.s.l) escarpment in the west. The valley floor is about $300 \mathrm{~m}$ lower in the western part and gradually rises towards the east, where there is no clear escarpment. Several small mountains are scattered throughout the Rift Valley, which are mostly volcano remnants. It is an important area for wildlife conservation, including or bordering the Lake Manyara, Arusha, Tarangire, Mount Kilimanjaro and Serengeti National Parks, as well as the Ngorongoro Conservation Area.

The climate of the study area is semi-arid and has four climatic seasons [29]. In general, the short rains season from November to January (NDJ) is followed by a short dry season (Feb) until the long rains start, which typically occur from March to May (MAM). From June to October (JJASO), a long dry season can be identified with cooler temperatures. Because of high interannual variability, the NDJ season often continues into February. In wet years the NDJ and MAM seasons often overlap in an almost continuous rainy season. The annual rainfall is between 450 and $1200 \mathrm{~mm}$, averaging around $750 \mathrm{~mm}$. The lower lying areas receive a mean annual rainfall of about $650 \mathrm{~mm}$, whereas in the higher parts the annual rainfall ranges from $1000 \mathrm{~mm}$ to $1200 \mathrm{~mm}$ on average [30,31]. The average temperature is between $20-25^{\circ} \mathrm{C}$, with a minimum of $11^{\circ} \mathrm{C}$ in July to September and a maximum temperature of $31^{\circ} \mathrm{C}$ in January and February [32,33].

The physical characteristics of the area, such as its morphology, geology and soils, are strongly influenced by tectonic activities and volcanism [3]. These characteristics have influenced the rainfall distribution, vegetation types and wildlife of the area. The Monduli district is part of the Lake Manyara catchment. Lake Manyara, part of an endorheic basin, is the southernmost lake within the eastern arm of the East African Rift System. The lake is shallow and saline, and is situated at $960 \mathrm{~m}$ a.s.l.

In the districts are multiple large volcanic mountains, both active and inactive. These mountains stand out in the dominantly flatter landscape, and often have higher rainfall on or near their slopes. Apart from the forests on the slopes of the mountains, savanna is the major land cover type. Savannas are generally on the transition area between tropical rainforests to deserts, which in this area is represented by the forests of the Monduli mountains, Mt. Meru and the Ngorongoro Conservation Area, and the drier, more arid regions of Simanjiro District and Dodoma Region in the south. The savannas have been managed extensively by the Masai through fire and grazing by their livestock, suppressing the growth of bushes and trees $[34,35]$. 


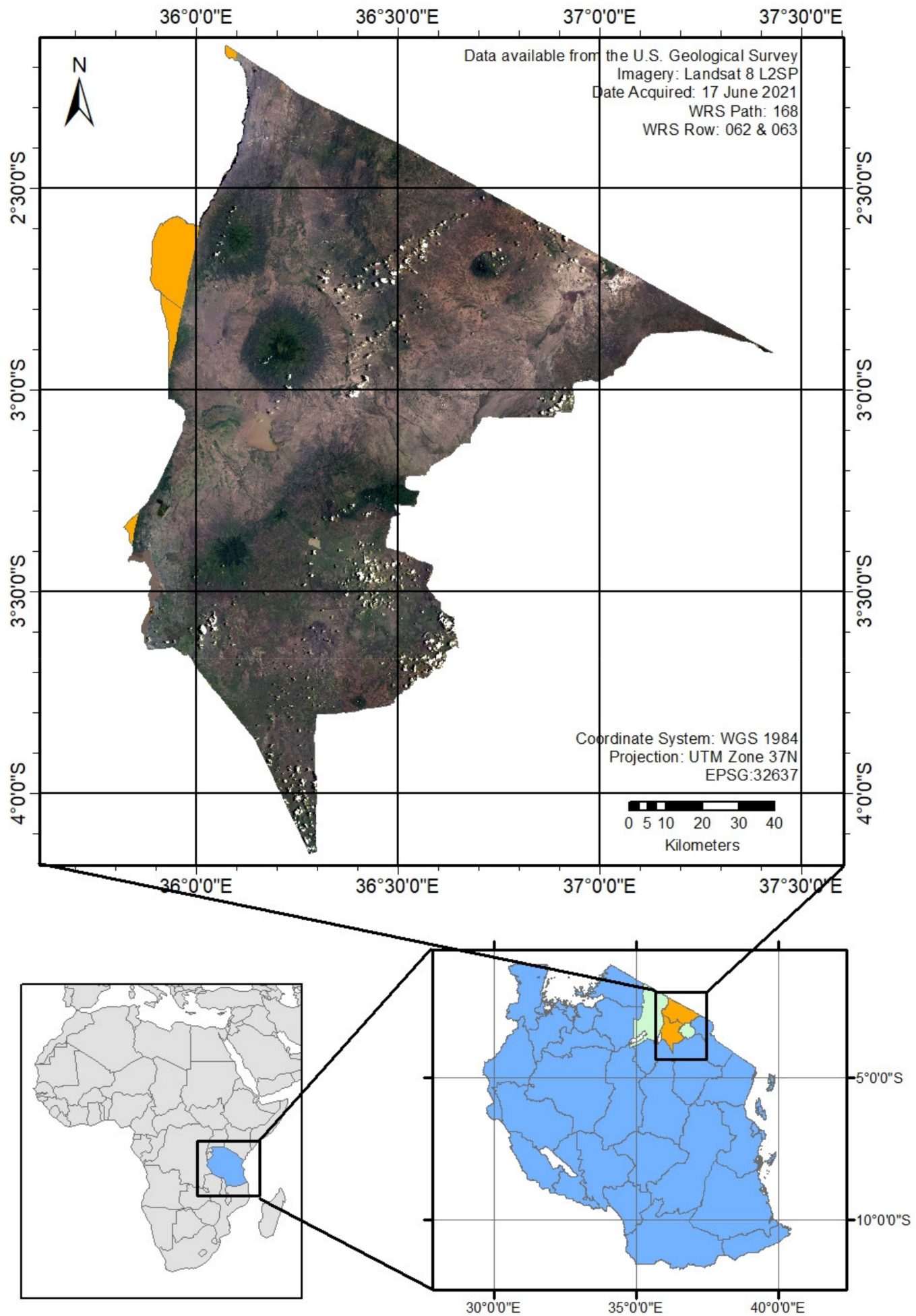

Figure 1. Study area: the Monduli and Longido districts within Arusha Region, northern Tanzania. Source: [27].

\subsection{Data}

The NDVI is an indicator of the vitality and density of vegetation of a remote sensing image pixel [36]. It is regarded as a reliable indicator for land cover conditions and variations, and over the years it has been widely used for vegetation monitoring [37]. The NDVI produced from historical satellite image archives captures long-term changes in vegetation health and density, enabling the measurement of responses to climate variability [38]. 
For this study we used the NOAA Climate Data Record (CDR) of AVHRR NDVI, Version 5. This dataset contains daily measurements of surface vegetation cover, gridded at a resolution of $0.05^{\circ}$ and computed globally over land surfaces [39]. The AVHRR provides data on a long-term basis (1981-current day) with a moderate spatial resolution. Other datasets could have a higher spatial resolution, but they were not suitable because they start providing data of the study area at a later date. The online platform Google Earth Engine (GEE) was used to extract the daily NDVI values of the study area. GEE is a high-performance cloud-based platform that gives access to a vast and growing amount of earth observation data and provides the processing power necessary to analyze the data [40]. The daily NDVI was used to compute 8-day maximum value composites to filter out cloud irregularities. Of these maximum value composites, the mean NDVI of the study area was used in this study.

The NDVI time series runs from 24 June 1981, the start of the AVHRR mission, until 24 June 2020. In 1988 a series of 51 negative NDVI values were measured, which coincides with the service start of a new AVHRR satellite (NOAA-11), and were therefore left out from further analysis. From week 36 in 1994 to week three in 1995 no data were available due to sensor malfunctioning [41,42].

The hydrometeorological data included the monthly precipitation and temperature of the study area. Limited in situ data were available as the study area is poorly gauged. However, reanalysis and satellite-based techniques can provide continuous hydrometeorological data. Monthly precipitation was obtained from the CenTrends v1.0 extended with the CHIRPS-2.0 dataset. The CenTrends dataset was developed for East Africa in particular to overcome the precipitation data gaps and to enable the analysis of seasonal and decadal fluctuations within a centennial context [43]. The CenTrends dataset is available from 1900. CHIRPS (Climate Hazards Group InfraRed Precipitation with Station data) is the state-of-the-art observational daily precipitation dataset for East Africa. CHIRPS uses additional infrared satellite data, and is therefore available from 1981. CenTrends and CHIRPS are non-independent datasets as they are based on a similar assimilation technique and underlying observational data for their overlap period. They are highly correlated (0.95), justifying the extension of the CenTrends dataset with monthly averaged data from CHIRPS [44]. The combination provides information about both trends in the past and present. The combined dataset was obtained via the KNMI Climate Explorer and has a spatial resolution of $0.2^{\circ}$.

The temperature data used in this study were obtained from the CRU TS4.03 monthly mean temperature. This dataset uses observations interpolated into $0.5^{\circ}$ latitude/longitude grid cells combined with existing climatology to obtain absolute monthly values [45]. The CRU was validated with the nearest available in situ data of a meteorological station. The in situ data were only available as mean monthly maximums. Therefore, the CRU TS4.03 mean monthly maximum temperature $\left(\mathrm{CRU}_{\max }\right)$ was validated with the available in situ dataset. With the use of the Pearson's $r$, the correlation of the datasets was tested. This statistical test was used because the datasets were continuous and normally distributed (Shapiro-Wilk normality test: $\mathrm{W}=0.97$ and $\mathrm{W}=0.95$ for, respectively, the in situ and the $\mathrm{CRU}_{\max }$ datasets, at $\left.p<0.05\right)$. The station mean monthly maximum temperatures measured at Arusha and $C R U_{\max }$ are in close correspondence $\left(r=0.96, R^{2}=0.91\right)$, but show relatively high deviations in terms of their magnitude (RMSE $=1.84^{\circ} \mathrm{C}$ ) for 1979 to 2018 . The strong correlation indicates a good representation of the annual temperature cycle. An overestimation of the $\mathrm{CRU}_{\max }$ data was determined at $\mathrm{T}<30.62{ }^{\circ} \mathrm{C}$ and an underestimation above this value was determined.

As both the CHIRPS and the CRU TS4.03 datasets are delivered grid-sized, the means of the monthly precipitation and the temperature of all grid cells were calculated for the area between coordinates $\sim 2-4^{\circ} \mathrm{S}, \sim 35-37^{\circ} \mathrm{E}$, which includes the study area. Drought and trends in precipitation and temperature were studied from 1940-2020, which is twice the temporal range of the NDVI data. 


\subsection{Trend Analysis}

The health of vegetation and the corresponding NDVI value is dependent on many anthropogenic and natural factors. The most important natural factors are temperature and precipitation [46]. Therefore, the variations in NDVI and hydrometeorological data were determined over time for the two rainy seasons (NDJ and MAM) and the hydrological year (September-August). All the datasets showed a non-normal distribution over the research period (Shapiro-Wilk normality test, $p<0.00$ ). Therefore, the Mann-Kenndall (MK) test was used to determine the direction and significance of trends. The MK test is a non-parametric rank-based test method which is widely used to assess the presence of trends in a time series of climatic, environmental or hydrological data [47-50]. The MK test results in a measure of the rank correlation of Kendall's $\tau$ (tau) and the significance ( $p$-value). The magnitude of the trend determined by the MK test was computed with Sen's slope. This test calculates both the slope and the intercept of a linear rate of change [51].

\subsection{Drought Analysis}

Due to the lack of data on stream flow, groundwater and soil moisture in the study area, only the occurrence of meteorological drought was investigated. The standardized precipitation evaporation index (SPEI) was used to determine drought. The SPEI is an extension of the standardized precipitation index (SPI), which uses only precipitation anomalies to determine drought [52]. To determine hydrological anomalies the SPI uses only precipitation, while the SPEI uses both precipitation $(\mathrm{P})$ and potential evapotranspiration (PET) to determine drought. It takes into account the impact of changing temperatures on water demand. This is important as evapotranspiration influences soil moisture variability and therefore vegetation water content [53]. PET was calculated in this study using the Thornthwaite equation [54], available in the SPEI package of the " $R$ " language. It requires mean temperature and latitude as input values. Other equations (e.g., Hargreaves or Penman) require variables for which no data were available for the study area. The mean temperature data of CRU TS4.03 were used. The SPEI focusses on the anomalies, and therefore the CRU data are assumed to be useful because of the high correlation with in situ data despite the reported overestimation. As the study area lies between $2-4^{\circ} \mathrm{S}$, a latitude of $-3^{\circ} \mathrm{N}$ was used in the Thornthwaite equation.

The SPEI measures P-PET anomalies based on a comparison of observations for a period of interest (e.g., 1, 3, 6, 12 and 48 months) with the long-term historical record of that period. It requires monthly data, preferably continuous and for 30 years or longer. For each month a SPEI value is calculated using the month itself and a previous number of months, which are together equal to the period of interest. For instance: when calculating the SPEI of March with a period of interest of 3 months, the cumulative P-PET of January, February and March is used. This value is then compared with the long-term record of cumulative January-March P-PET. The period of interest of the SPEI represents typical time scales for water deficits to affect different types of water sources. For example, the 1- or 3-month SPEI represents short droughts and indicates immediate impacts, such as reduced soil moisture, while the 12- or 24-month SPEI represents long droughts, causing, for instance, changes in reservoir storages [52]. In this study the 3-month SPEI (SPEI-3) was used to represent short-term droughts, while the 12-month SPEI (SPEI-12) values were used to represent annual (medium-term) and multi-annual (long-term) droughts. Furthermore, the SPEI-3 was used to indicate dry/wet seasons and the SPEI-12 was used to indicate dry/wet years within the study period.

To calculate the SPEI, the P-PET record is fitted to a probability distribution (loglogistic) function. It is then transformed into a normal distribution with a mean of zero and a variance of one. The result is the SPEI, which represents the number of standard deviations from the mean. Positive SPEI values indicate anomalous wet periods, and negative values indicate dry periods $[52,53,55]$. The magnitude of the SPEI gives a probabilistic measure of drought/wetness intensity. For instance: an SPEI-3 equal to -2 in January-March of a certain year means that the cumulative January-March P-PET of that year is 2 standard 
deviations smaller than the long-term average of cumulative January-March P-PET. Events were defined according to the drought intensity classes of McKee et al. [52]: a drought event was classified when the index was below -1 and a wet event was classified when the index was higher than 1 (Table 1). Some studies suggest a denotation of -0.5 to 0.5 for normal conditions [56,57]; however, due to the adaptation of the vegetation to semi-arid conditions the effects of a mild drought on the vegetation are assumed to be neglectable.

Both seasons (NDJ and MAM) and years were classified as dry, wet or normal using the SPEI. Here, the SPEI-3 of January and May were considered for, respectively, the NDJ and MAM seasons. To determine whether a hydrological year was wet, dry or normal, the SPEI-12 of August was used as this value is based on the previous September-August P-PET values.

Table 1. SPEI-based classification of drought. Based on temperature and precipitation during a given moment at a specified latitude, the SPEI gives anomalies of that given moment compared to other years. Source: [52].

\begin{tabular}{ccc}
\hline SPEI & Classification & Expected Probability (\%) \\
\hline 0 to -0.99 & Mild drought & 34.1 \\
-1.00 to -1.49 & Moderate drought & 9.2 \\
-1.50 to -1.99 & Severe drought & 4.4 \\
$\leq-2.00$ & Extreme drought & 2.3 \\
\hline
\end{tabular}

\subsection{Vegetation Resilience}

The resilience of vegetation was tested for multi-annual (long-term), annual (mediumterm) and seasonal (short-term) responses to drought. The 8-day maximum value composited NDVI and the SPEI values were used to investigate the effects of drought on vegetation cover and resilience.

The long-term effect of changing climate conditions on vegetation cover is represented by changes in the NDVI values over the years. Such changes over time in the NDVI values represent a change in vegetation cover and vegetation health [58]. This was tested with the MK test of 8-day maximum value composited NDVI from 1981 to 2020 and compared to the long-term precipitation and temperature in the region. With the use of Sen's slope [51], the linear rate of change was calculated.

The annual (medium-term) dynamics in vegetation cover and its response to drought were quantified by separating the years into different classes based on hydrological conditions. Dry, normal and wet years were classified with the use of the SPEI-12. Additionally, the year following a dry year was classified as a "recovery-year", regardless of the hydrological conditions of that year. The data of each of those four classes were than fitted by using local polynomial regression (LOESS) to provide a smooth curve through a set of datapoints. The response of the NDVI throughout the seasons was then compared for these four different hydrological conditions. In a second step, vegetation resilience over time was evaluated. For this purpose, three time periods were selected: 1991-2000; 2001-2010; and 2011-2020. If the resilience was not affected over the long-term, similar intra-annual NDVI values were expected during dry years in each time period. The time periods were chosen to have an approximate equal number of years classified as dry (SPEI-12 in August $<-1$ ). The years 1981-1990 were left out because no drought had occurred during these years.

Finally, the seasonal (short-term) effect of drought on vegetation cover and resilience was evaluated. The dynamics of vegetation response to seasonal droughts were tested by comparing intra-annual NDVI trends during dry and non-dry periods. It was assumed that if the vegetation has adapted to the semi-dry environment, it will withstand droughts by reviving as soon as the conditions permit [59]. This would mean that the regrowth of the vegetation is not dependent on the severity of a drought, as indicated by the SPEI values. Hence, it was expected that the NDVI values of the subsequent non-dry season do not deviate substantially from other normal (non-dry) years. Seasonal resilience was tested by comparing the sinusoidal curve of the intra-annual NDVI pattern of dry years and the 
following normal or wet year. Moreover, the effect of the timing of a drought during a dry year was assessed. The timing of the drought was determined with the use of the SPEI-3. The moment of drought was characterized as an SPEI-3 smaller than -1 during the first or the second rainy season (NDJ or MAM, respectively). Four situations were compared, in which both seasons were dry (two occurrences), the first or the second season was dry (four occurrences for both situations) or both seasons were normal or wet (thirteen occurrences). The curves of the NDVI during these different timings of the drought show the response of vegetation to the seasonal drought, and thus provide a proxy of vegetation resilience.

\section{Results}

\subsection{Rainfall and Temperature}

Variations in precipitation during the NDJ and MAM rainy seasons as well as the hydrological year are shown in Figure 2. The rainfall in the study area is characterized by a high but mainly homogeneous variation in seasonal rainfall (Figure 2A,B) and annual rainfall (Figure 2C). Overall, the NDJ season has a higher variation than the MAM season $\left(\mathrm{CV}_{\mathrm{NDJ}}=0.49 ; \mathrm{CV}_{\mathrm{MAM}}=0.32\right)$, but on average rainfall in the NDJ season is lower compared with the MAM season (226 mm vs. $327 \mathrm{~mm}$ ) (Table 2).

The precipitation has a slightly decreasing trend in the MAM season and annual rainfall, and a small increasing trend in NDJ rainfall (Figure 2). However, all trends are insignificant according to the MK test (Table 3), which means it cannot be concluded that the amount of rainfall has changed in the study area over the period of 1940-2020. Temperature on the other hand does show a significant $(\alpha=0.05)$ increasing trend (Figure 3$)$. This positive trend was observed both for the yearly averaged temperature as well as for the seasonally averaged temperatures (NDJ and MAM) (Table 3). Deviations from this trend in the form of relatively warm (e.g., 1951-1952) and cold (e.g., 1967) years are also visible. Overall, the yearly average temperature increased by $1.06^{\circ} \mathrm{C}$ between 1940 and 2020.

Table 2. Statistics of seasonal and annual precipitation and temperature during the period of 19402020 in northern Tanzania. Trend based on Sen's slope. During the warmer NDJ season there is, on average, less precipitation with a higher level of variance compared to the MAM season.

\begin{tabular}{ccccccc}
\hline & \multicolumn{3}{c}{ Precipitation } & \multicolumn{3}{c}{ Temperature } \\
\cline { 2 - 7 } Period & $\begin{array}{c}\text { Trend } \\
(\mathbf{m m} / \text { Decade) }\end{array}$ & $\begin{array}{c}\text { Average } \\
\mathbf{( m m )}\end{array}$ & $\mathbf{C V}^{\mathbf{1}} \mathbf{( - )}$ & $\begin{array}{c}\text { Trend } \\
\left({ }^{\circ} \mathbf{C} / \text { Decade) }\right.\end{array}$ & $\begin{array}{c}\text { Average } \\
\left({ }^{\circ} \mathbf{C}\right)\end{array}$ & $\mathbf{C V}^{\mathbf{1}} \mathbf{( - )}$ \\
NDJ & 5.7 & 226 & 0.49 & 0.12 & 22.1 & 0.020 \\
MAM & -3.7 & 327 & 0.32 & 0.12 & 21.8 & 0.022 \\
Annual (Sept-Aug) & -4.5 & 656 & 0.27 & 0.13 & 21.3 & 0.019 \\
\hline
\end{tabular}

1 , coefficient of variation.

Table 3. Seasonal and annual Mann-Kendall test trend results of rainfall and precipitation over the period of 1940-2020 in northern Tanzania. At $\alpha=0.05$ the temperature is significantly increasing, but the precipitation is insignificant.

\begin{tabular}{ccccc}
\hline \multirow{2}{*}{ Period } & \multicolumn{2}{c}{ Precipitation } & \multicolumn{2}{c}{ Temperature } \\
\cline { 2 - 5 } & Tau & $p$-Value & Tau & $p$-Value \\
\hline NDJ & 0.117 & 0.12 & 0.448 & $<2.2 \times 10^{-16}$ \\
MAM & -0.0877 & 0.25 & 0.411 & $1.19 \times 10^{-7}$ \\
Annual (Sept-Aug) & -0.0247 & 0.75 & 0.569 & $<2.2 \times 10^{-16}$ \\
\hline
\end{tabular}



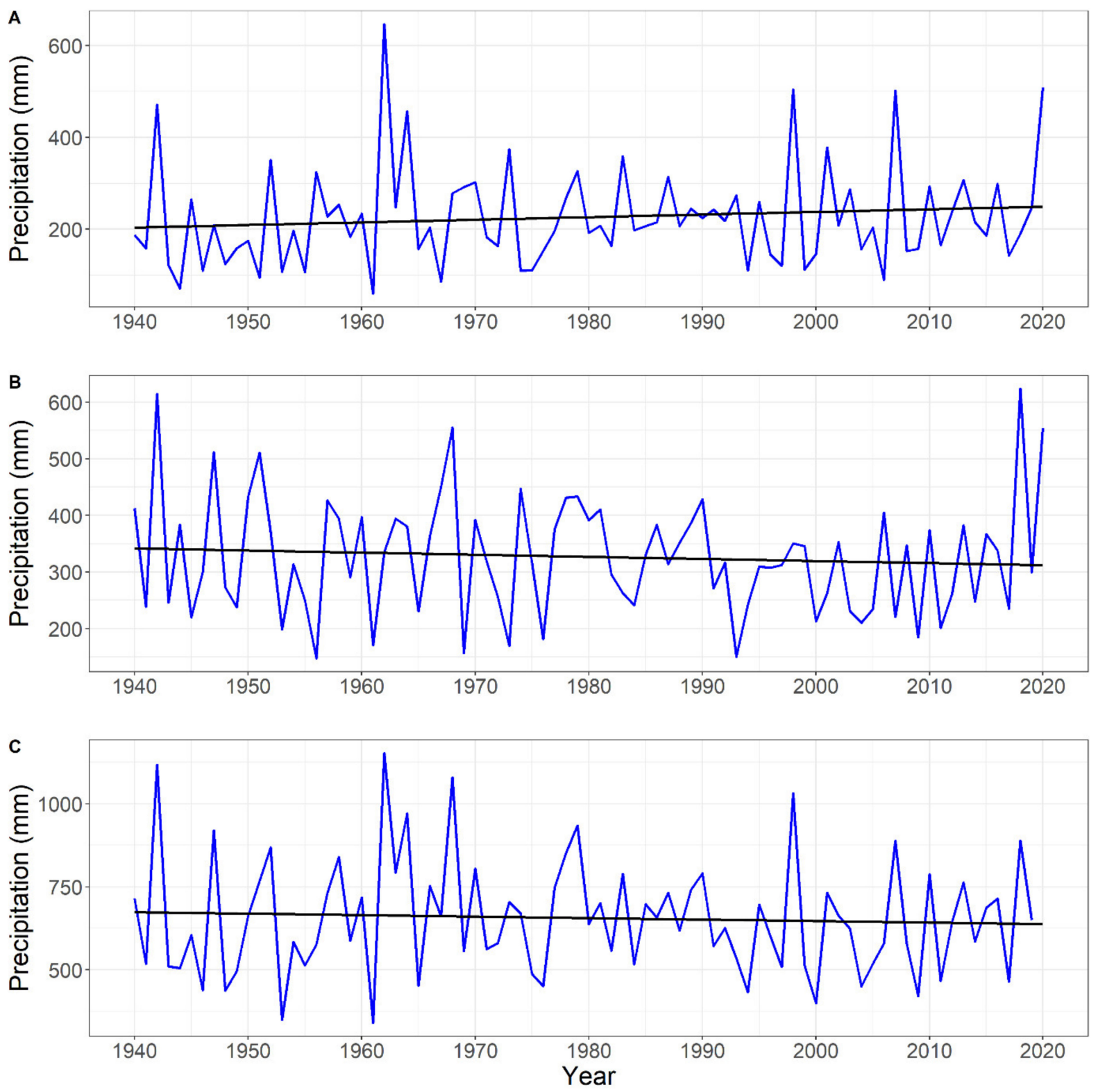

Figure 2. Total amounts of rainfall in northern Tanzania during the period of 1940-2020 based on the CenTrends v1.0 dataset extended with CHIRPS-2.0. (A) The NDJ (November, December and January) rainy season, (B) the MAM (March, April and May) rainy season and (C) the hydrological year (Sept-Aug). Linear trend lines (black) are based on Sen's slope. Insignificant at $\alpha=0.05$. The NDJ-season has a higher variability compared to the MAM-season $(\mathrm{CV}=0.49$ and 0.32 , respectively), but a lower seasonal mean (226 and $327 \mathrm{~mm}$, respectively). 


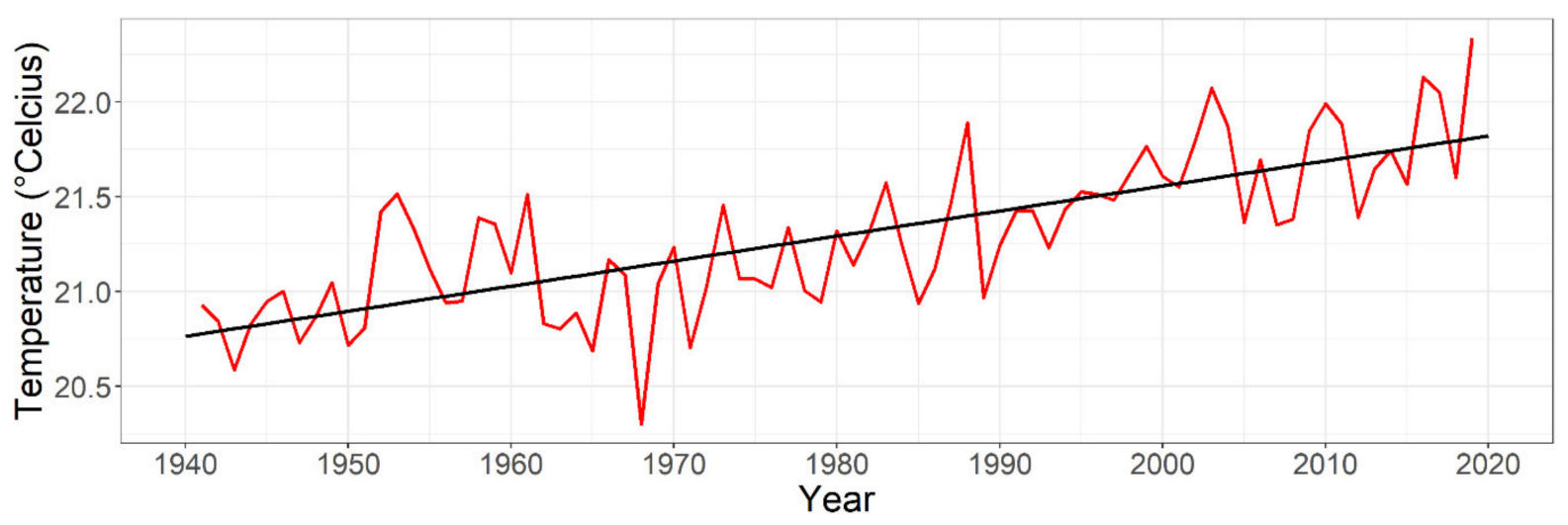

Figure 3. Average annual temperature in northern Tanzania during the period of 1940-2020 based on monthly mean data of the CRU TS4.03 dataset. Linear trend (black) based on Sen's slope. Significant at $\alpha=0.05$, increase of $0.13^{\circ} \mathrm{C} / \mathrm{decade}$.

\subsection{Drought Occurrence}

The SPEI was calculated for periods of 3 months (SPEI-3), representing short-term dry or wet seasons, and 12 months (SPEI-12), representing medium-term drought/wet years. Figure 4 shows SPEI-3 and SPEI-12 time series over the time period of 1940-2020. As expected, fewer drought events are identified with the SPEI-12 compared to the SPEI-3 time series. Multiple smaller events identified by the SPEI-3 can either be flattened out or cumulated into one event of the SPEI-12. The latter effect is known as pooling [60]. Relatively wet and dry years can be distinguished, with either largely positive SPEI-12 values (e.g., the 1960s) or negative SPEI-12 values (e.g., the period of 1999-2006).

Both SPEI time series show a significant decreasing trend (SPEI-3: tau $=-0.157, p$ value $=4.1 \times 10^{-13} ;$ SPEI-12: tau $=-0.148, p$-value $=7.4 \times 10^{-12}$ ). This means that a drying trend is present in the study area, which is mainly the effect of the increasing temperature, given the non-significant changes in rainfall in the study area. Higher temperatures result in higher potential evapotranspiration values, which lead to overall more negative SPEI values. The drying trend since 1940 is also reflected by the relatively large area below zero (=dry) compared to the area above zero (=wet) in recent decades (1990-2020).

Zooming into the time period of the NDVI data (1981-2020), the 1980s was a decade which barely shows long or extreme dry and wet events. The 1990s and 2000s are characterized by more frequent and longer droughts. The period of 2001-2010 in particular suffered from extended and severe droughts, with some SPEI values going below -2 (extreme drought). The differences in drought severity between decades is reflected by the occurrence of low SPEI-3 and SPEI-12 values presented in Table 4. Assuming a normal distribution of the SPEI, the occurrence of SPEI $<-1$ or SPEI $>1$ would occur $15.9 \%$ of the time and the mean would be 0 . However, every decade since 1980 has fewer wet events, and since 1991 more dry events have occurred than expected. The 2001-2010 decade was the driest period, represented by a high occurrence of droughts and a low mean SPEI value over time, while the 2011-2020 decade experienced similar droughts as the 1991-2000 decade. During the 1981-1990 decade the study area experienced a low number of moderate to extreme events, which is also reflected by the steady rainfall values over this time period (Figure 2). Before 1980, several periods of serious drought occurred, for instance during 1953-1956 and 1975-1977 (Figure 4). 
Table 4. Percentage of total SPEI values per decade and mean SPEI values per decade. Based on the definition of SPEI, the mean over the entire research period is 0 , and the total of moderate to extreme wet/dry seasons $(-1>$ SPEI $>1)$ should not exceed $15.9 \%$ of the time (Table 1$)$. During the four most recent decades this is not the case.

\begin{tabular}{ccccccc}
\hline Period & \multicolumn{3}{c}{ SPEI-3 } & & \multicolumn{3}{c}{ SPEI-12 } \\
\hline & $<-\mathbf{1}$ & $>\mathbf{1}$ & Mean & $<-\mathbf{1}$ & $\boldsymbol{> 1}$ & Mean \\
\hline & $\mathbf{\%}$ & $\mathbf{\%}$ & - & $\mathbf{\%}$ & $\mathbf{\%}$ & - \\
\hline $1981-1990$ & 5.0 & 11.7 & 0.138 & 0.8 & 7.5 & 0.247 \\
$1991-2000$ & 25.0 & 6.7 & -0.353 & 28.3 & 9.2 & -0.470 \\
$2001-2010$ & 34.2 & 8.3 & -0.437 & 30.0 & 9.2 & -0.482 \\
$2011-2020$ & 19.2 & 10.0 & -0.309 & 17.5 & 9.2 & -0.285 \\
\hline
\end{tabular}
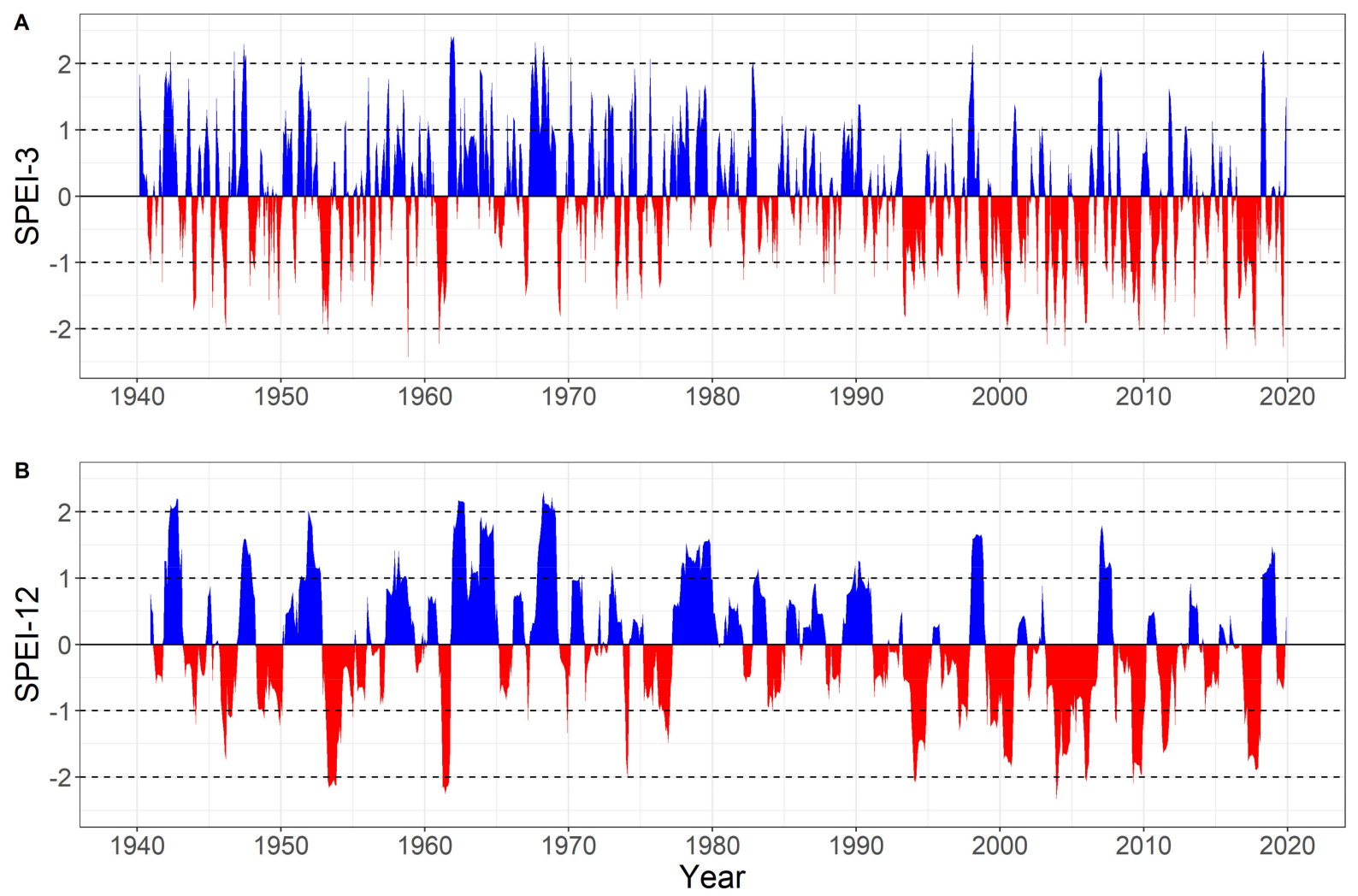

Figure 4. SPEI-3 (A) and SPEI-12 (B) values of 1940-2020. Blue indicates relatively wet conditions, while red indicates relatively dry conditions in the indicated ( 3 or 12) antecedent time period in months. Significant $(\alpha=0.05)$ negative trends were found in both the SPEI-3 and SPEI-12.

\subsection{Vegetation Cover and Resilience}

The effects of droughts and seasonal rainfall on the resilience of vegetation in the area were assessed by comparing the NDVI time series with the SPEI-3 and SPEI-12 values. Trend analysis was applied to the long-term NDVI time series and a visual comparison was applied to the intra-annual variations.

The NDVI values over the years (1981-2020) show a seasonal pattern, with relatively high NDVI values in the period of the two wet seasons, and low values during the dry season (Figure 5). The higher NDVI values indicate healthy vegetation with a high cover, while the lower values indicate bare soil or low vegetation cover. Figure 5 also shows that the NDVI values are generally lower during dry periods, as indicated by the negative SPEI-3 values. 


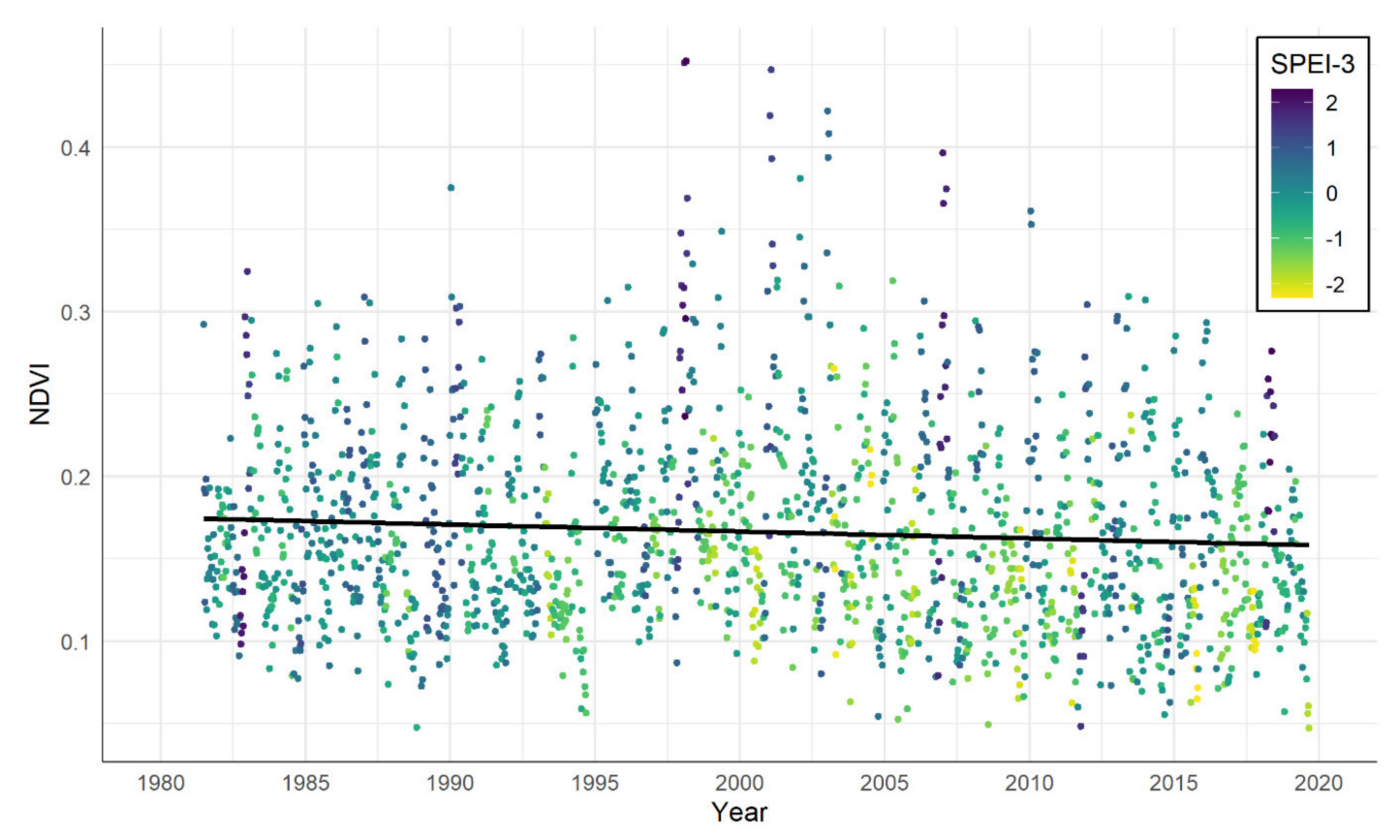

Figure 5. Interannual normalized difference vegetation index (NDVI) series, composed of 8-day maximum value composited NDVI. The NDVI values were classified according to SPEI-3 values, which indicates drought (strong negative SPEI-3 values) or wet (strong positive SPEI-3 values) conditions. A trend line (black) was fitted through all data based on Sen's slope (significant at $\alpha=0.05$ ).

The long-term NDVI has a significant downward trend (tau $=-0.0623, p$-value $8.38 \times 10^{-5}$, Sen's slope $\left.=-1.02 \times 10^{-5}\right)$. This downward trend results in a decrease of 0.017 NDVI points (from 0.175 to 0.158 ) between 1981 and 2020. Therefore, over the period of analysis, on average, vegetation cover in the study area has declined. Several possible reasons for this vegetation cover decline can be given. The first is the conversion of grazing land to arable land for crop production $[23,24]$. The second possibility is land degradation due to overgrazing in the area $[23,25]$. The last reason could be the increased temperatures and drought as exemplified by the SPEI values (Figure 4).

Figure 6 shows the same 8-day NDVI values as in Figure 5, but in this figure the values have been plotted versus the hydrological year (Sept-Aug). The polynomial regression lines of NDVI values for dry (red; SPEI-3 $<-1$ ), wet (blue; SPEI-3 $>1$ ) and normal years (black; $-1<$ SPEI- $<1$ ) are also plotted. An additional regression line (yellow color) shows the NDVI values for a year immediately following a drought year. Obviously, the wet years have higher NDVI values than normal years, and thus better vegetation cover. During dry years, the NDVI values are substantially lower than in normal years, indicating less vegetation cover or less healthy vegetation. However, in the years following a drought year, the NDVI values return to normal values, which indicates a high resilience of vegetation in the study area. Apparently, the drought is affecting the vegetation temporarily, but during the period of study (1981-2020) it has not led to dramatic vegetation degradation, apart from the slightly negative long-term trend that was detected (Figure 5).

The intra-annual NDVI time series has been split into three decades: 1991-2000, 20012010 and 2011-2020 (Figure 7). In each decade, two or three years were classified as dry years (SPEI-12<-1). The polynomial regression curves show that in the first (Figure 7A) and last decade (Figure 7C) the NDVI values in a year following a drought year quickly return to normal values. In the decade 2001-2010, which experienced the most droughts, the NDVI values following a drought year also return to nearly similar levels as the longterm normal. The normal year NDVI values in this decade are higher than in the other two decades, which is surprising given the more severe drought conditions in this decade (Table 4). Apparently, the rainfall was well-distributed during the normal years in the period of 2001-2010, which resulted in good vegetation growth during those normal years. 


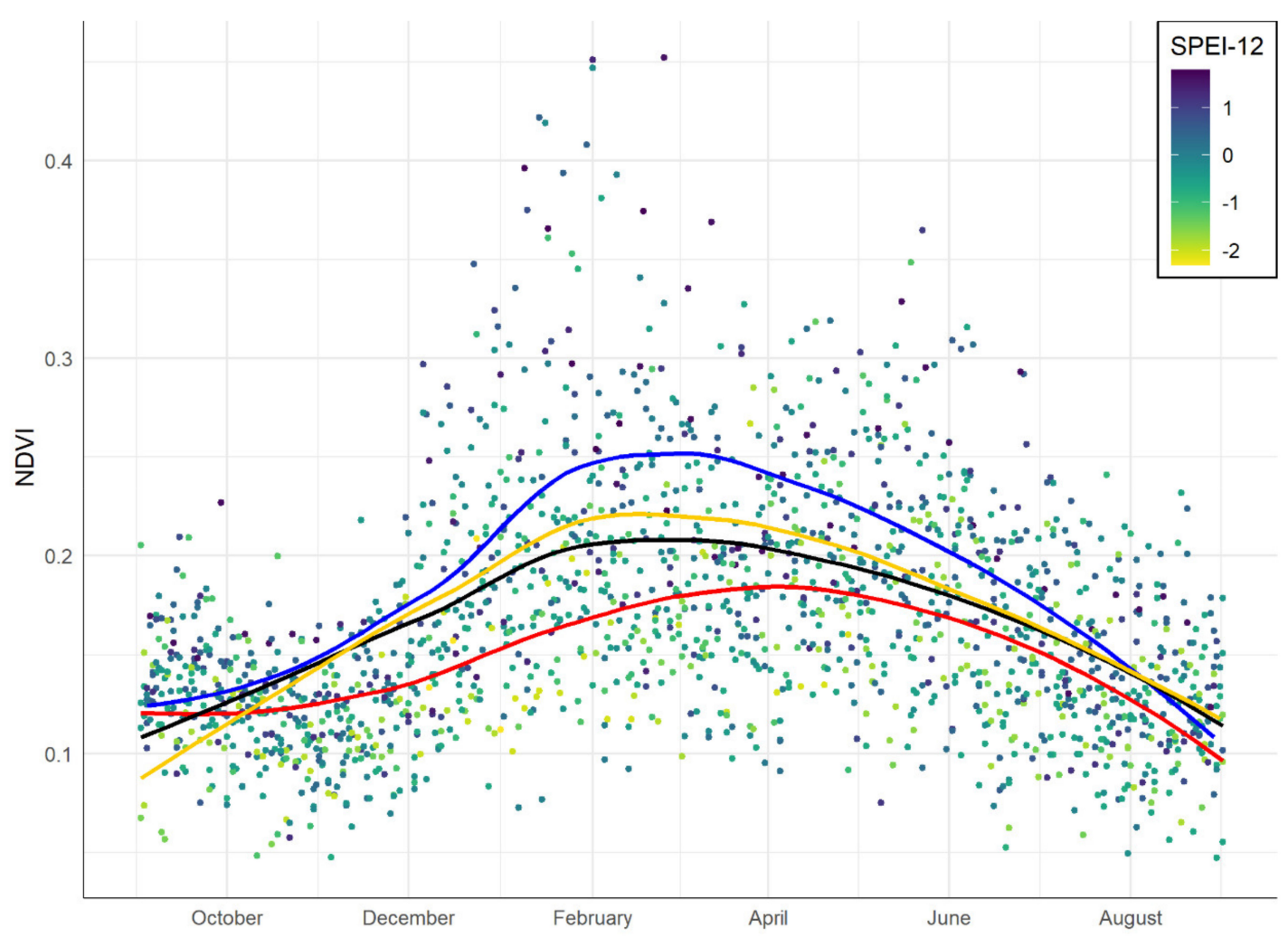

Figure 6. Intra-annual NDVI series, based on 8-day maximum value composited NDVI from 1981 to 2020. Based on the SPEI-12 of the hydrological year, the lines represent the NDVI values belonging to normal (black), dry (red) or the year subsequent to a dry hydrological year (yellow) with the use of locally estimated scatterplot smoothing (LOESS).
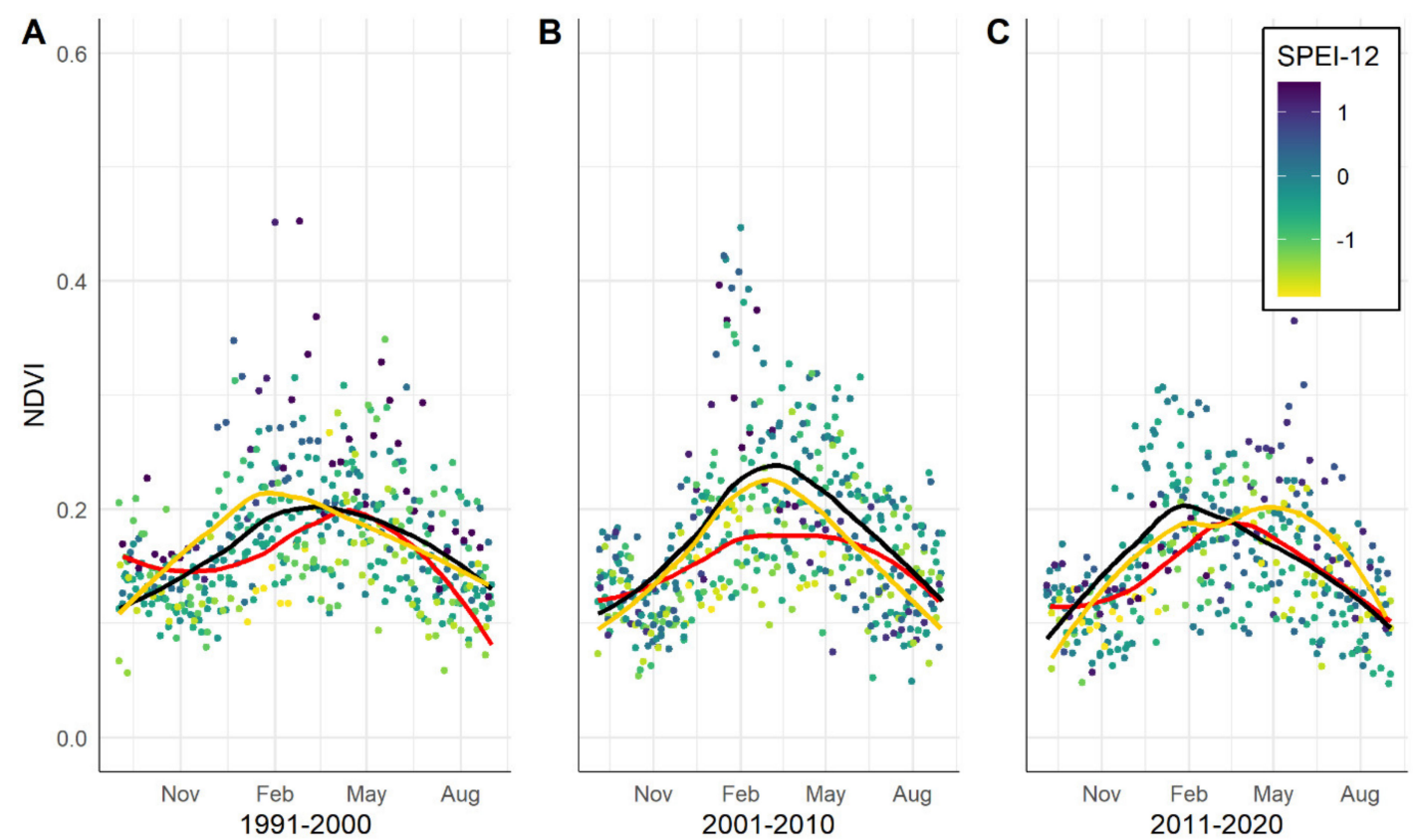

Figure 7. Intra-annual decadal NDVI series, composed of 8-day maximum value composited NDVI from (A) 1991-2000, (B) 2001-2010 and (C) 2011-2020. The lines represent the NDVI values belonging to normal (black), dry (red) or the year subsequent to a dry hydrological year (yellow) with the use of locally estimated scatterplot smoothing (LOESS).

In the last analysis, the impacts of seasonal droughts on NDVI development were evaluated. The short-term effects of drought were tested with the use of the SPEI-3 for 
the NDJ and MAM seasons. The NDJ season was classified as dry when the SPEI-3 of Jan was below -1 . The MAM rainy season was considered dry when the SPEI-3 of May was below -1 .

The timing of the drought during the hydrological year has an effect on the pattern and magnitude of the NDVI values (Figure 8). During a year in which both the short rainy season (NDJ) is normal and the long rainy season (MAM) is normal the NDVI reaches its peak of $\sim 0.20$ in early March (dark-green curve in Figure 8 ). On the other hand, the occurrence of drought during the NDJ, MAM or both seasons impacts the development of the NDVI over time. If the NDJ rainy season is normal the NDVI will pass the curve of two normal seasons at first but will decline more quickly during a dry MAM season (yellow curve). A year with a dry NDJ but normal MAM seasons (blue curve) shows a delay in the development in the NDVI but reaches similar peak values as in a normal year. The peak values of NDVI are reached about 1.5-2 months later than in a normal year, before subsequently declining again. This either indicates that the vegetation recovery from the dry NDJ season requires some time, or that vegetation cover in a normal year reduces more quickly due to heavy grazing, which can start much earlier in a good rainfall year.

The duration of increased NDVI levels is similar if one of the rainy seasons is a dry season. However, if both seasons are classified as dry (purple curve), this time period is shorter. The purple curve shows that despite both seasons being classified as dry, the MAM season still has enough rainfall to enable vegetation growth, albeit not as good as during a normal or wet MAM season. The minimum amount of rainfall in the MAM season is $\sim 150 \mathrm{~mm}$ (Figure 2B), and in the two years that comprise the purple curve in Figure 8 the MAM precipitation was $210 \mathrm{~mm}$ (2004) and $235 \mathrm{~mm}$ (2017). This explains the relatively good vegetation cover in the MAM rainy season that on average has $78 \mathrm{~mm}$ more precipitation than the NDJ season (Table 2).

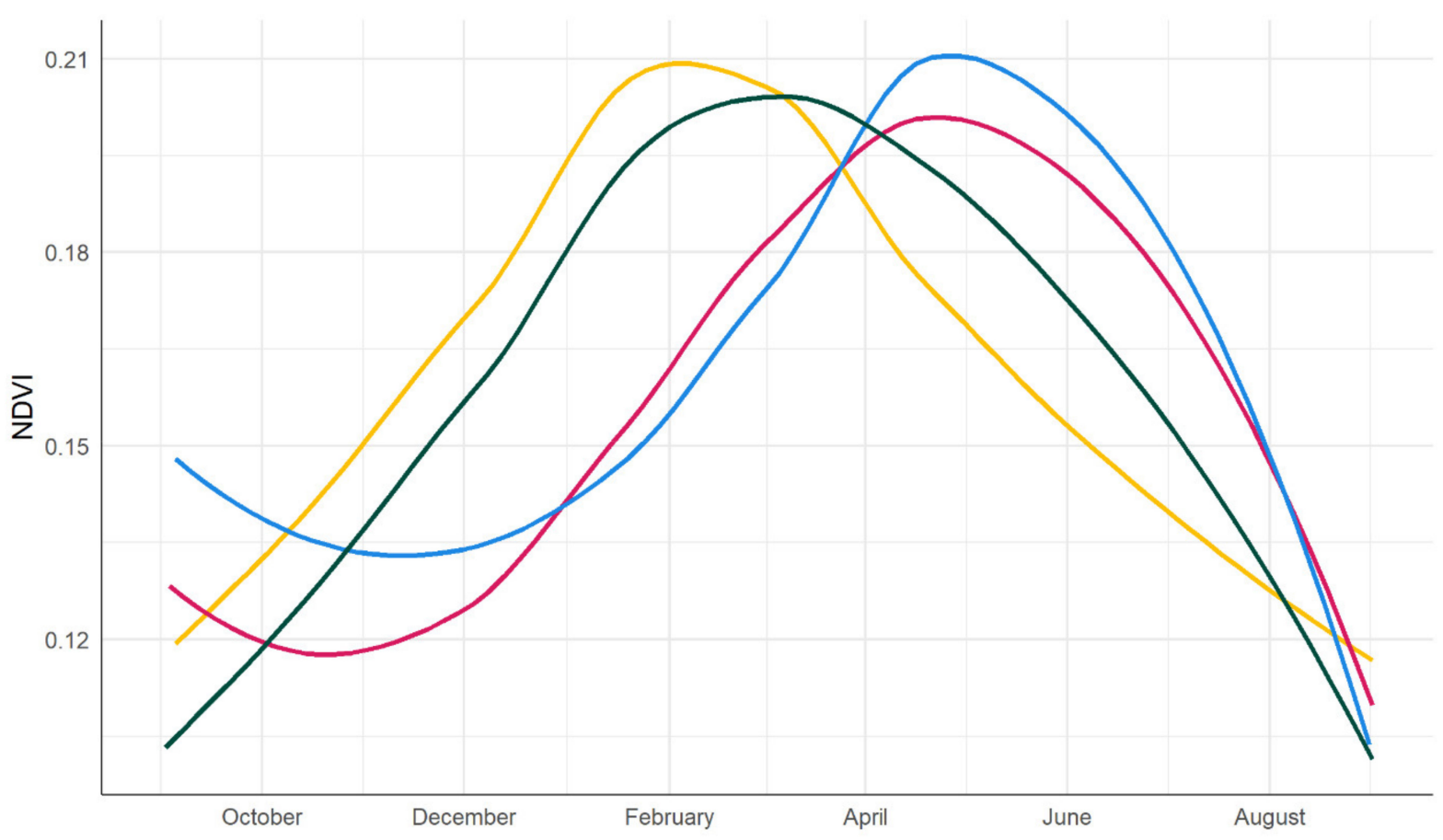

Figure 8. Seasonal NDVI response to different drought regimes between 1991 and 2020. The dark-green line represents a normal season, both during the NDJ and the MAM. The purple line represents two dry seasons, blue represents a dry NDJ followed by a normal MAM season and yellow represents a normal NDJ followed by a dry MAM season. 


\section{Discussion}

\subsection{Rainfall and Temperature}

The total annual rainfall and the rainfall during the NDJ or MAM rain season in the study area did not change significantly $(\alpha=0.05)$ during the period of 1940-2020 (Table 3). These results contradict the results of earlier research which indicated decreasing East African rainfall due to lower MAM rainfall since the early 1980s [61-63]. The reason given for the declining rainfall is the rapid warming of the Indian Ocean, which leads to stronger convection and more rainfall over the Indian Ocean and less rainfall in East Africa. Our data for Monduli and Longido districts do not confirm those reported results, as the rainfall trends are all insignificant.

The rainfall data of the study area (Figure 2) are characterized by a high interannual variation in amounts of rainfall. As in other semi-arid regions, mean annual rainfall does not often occur; many years had much lower or much higher amounts of rainfall. This is also reflected by the seasonal amounts of rainfall. In most years the NDJ rainfall was below average, and in only a few years it was well above the average (e.g., 1962, 1998 and 2007), which leads to a positively skewed distribution (skew $=1.33$ ). The MAM rainfall was less variable than the NDJ rainfall and more evenly distributed around the mean $(\mathrm{skew}=0.56)$. The hydrological years (Sept-Aug) in which the amounts of rainfall were below average are usually caused by a lack of rainfall in one of the rainy seasons. During only 12 out of 80 years both rainy seasons were more than $25 \%$ below average. For the NDJ season this occurred in 28 of the 80 years, and for the MAM season this occurred in 21 years. For the rainfall in the hydrological years, the contribution of the MAM season varied from 24 to $76 \%$, but on average it was $50 \%$. The NDJ season contributed between 14 and $64 \%$ of rainfall to the hydrological year. On average this was $37 \%$.

Unlike the amounts of rainfall, the temperature in the study area increased significantly $\left(\alpha=0.05\right.$ ) by $1.06{ }^{\circ} \mathrm{C}$ over the period of $1940-2020$. A highly significant increasing trend was determined and can only be caused by global warming [64]. According to [65] the warming in East Africa started in the early 1980s, but our data series (Figure 3) shows that a more or less steady increase in temperature had already started since 1940. Only the 1960s were relatively cool, but since then the increase in temperature was again steady and approximately $0.12{ }^{\circ} \mathrm{C}$ per decade. This warming may have resulted in a more erratic rainfall pattern with higher rainfall intensities due to the stronger convection [66]. However, the rainfall data used in the study do not provide any information on the rainfall character, and thus it cannot be confirmed that the rainfall has actually become more extreme.

\subsection{Drought}

Occurrence of drought in the study area was analyzed using the SPEI-3 (short-term droughts) and SPEI-12 (long-term droughts). Both SPEI time series (Figure 4) show a significant $(\alpha=0.05)$ decreasing trend in SPEI values, indicating that drought has become more serious recently than it was in the past in the Monduli and Longido districts. As no significant changes in rainfall occurred, the enhanced drought can only be the result of the warming of the area. Increasing temperature will result in a higher potential evapotranspiration [54], which will lead to stronger desiccation of the land, and thus more drought stress in semi-arid areas such as the Monduli and Longido districts. Since 1993, six long-term droughts (SPEI-12<-1) have occurred, while in the 53 years prior to 1993 only three of such droughts occurred. A similar pattern can be observed for short-term droughts (SPEI-3 $<-1$ ). A notable period without much drought was the period from the late 1970s until the early 1990s (Figure 4 and Table 4).

It is difficult to compare our results with other studies, as study designs may be different in timescales, datasets, research periods or study areas [67]. The importance of the latter is underlined by $[68,69]$, which studied the Greater Horn of Africa and obtained large spatiotemporal variations in trends in precipitation and temperature between 1980 and 2010 [68], and trends in SPEIs between 1964 and 2015 [69]. A recent study on the entire Lake Manyara catchment, including the Monduli and Longido districts, showed 
the presence of a drying trend over the past century [22]. Furthermore, a general increase in decadal drought characteristics (duration, severity and frequency) from the 1930s to present, with the exception of the wet 1980s, was reported by [22].

The observed increasing drought is in agreement with local people that state that it is drier and warmer nowadays compared to 25-30 years ago [25]. The drying trend may raise concerns for the future of the Monduli and Longido districts. Conway et al. [70] analyzed the results of 34 climate models that simulated future precipitation and temperatures in Tanzania. These results showed wide spatiotemporal variations within Tanzania regarding future precipitation. The results indicate that the number of rainy days will decrease and the that the intensity of events will increase. This suggests more variable rainfall with a higher chance of droughts or floods in the future. In contrast to rainfall, the climate models predict increasing temperatures between 0.8 and $1.8^{\circ} \mathrm{C}$ for 2040 in addition to between 1.6 and $5.0^{\circ} \mathrm{C}$ for 2090 (relative to the period of 1976-2005). The change is evenly distributed across Tanzania. Thus, while future changes in precipitation are uncertain, it can be stated that temperatures will continue to rise, which will further increase the drought risk in the study area due to higher potential evapotranspiration rates.

\subsection{Vegetation Trends and Resilience}

Based on the NDVI timeseries a significant $(\alpha=0.05)$ decline in vegetation cover was observed between 1981 and 2020 (Figure 5). The fitted trendline indicates that the average NDVI declined by $9.7 \%$, from 0.175 in 1981 to 0.157 in 2020. This observed decline in vegetation cover is less dramatic than previously reported numbers in other studies on East Africa [1,23,71], which generally show 1.5 to 3 times more vegetation reduction than our results. It is not clear why those other studies come to these higher vegetation cover decline values for the same study area. One reason could be that our analysis is based on near-continuous NDVI values while most other studies take NDVI values from fewer moments in time. As clearly visible in Figure 5, the timing of the satellite imagery for NDVI calculation can result in rather different NDVI values. This is equally true for the year (dry versus wet) which is chosen and the timing of the image within that year (dry season versus wet season).

The decline in vegetation cover observed here could be the result of different causes. Parts of the study area have been converted from grassland into arable land, which on average has lower vegetation cover [23,24]. Additionally, vegetation degradation due to overgrazing leading to bare soil might play a role in the contemporary lower vegetation cover $[23,25,32]$. Finally, the increase in drought severeness and frequency (Figure 4) might also result in generally lower vegetation cover. Drought will not only reduce the amount of green vegetation but will also affect the condition of the growing plants, which is reflected by a lower NDVI [72]. Based on the available data and analyses, it is not possible to conclude which of these reasons is the most important, and it could well be that all reasons play a role in the declining vegetation in the study area. However, given the significant increase in drought occurrence in the study area (Figure 4), it is believed that drought is the main cause of declining vegetation cover.

Vegetation resilience of the study area can be characterized as high. When a year was dry the NDVI values were lower than in a normal year, meaning less vegetation cover, but the next year the vegetation always recovered to normal year values (Figure 6). The recovery of the vegetation following a drought year did not change over time (Figure 7). In the 2011-2020 decade the resilience was not different from the 1991-2000 and 2001-2010 decades. At the seasonal scale, vegetation resilience appeared to be good. A dry season resulted in lower vegetation cover, but the vegetation came back quickly during the next normal or wet season and reached similar NDVI values (Figure 8).

These results show that, despite a general decline in vegetation cover over the period of 1981-2020, vegetation resilience was still good in the Munduli and Longido districts. Drought had an immediate impact on vegetation cover, but once rains came back at normal or above normal levels in a new season the vegetation quickly responded and returned to 
normal levels. However, what NDVI observations do not tell is possible changes in the species composition. Pressures on the grazing systems could be drought and overgrazing, which may lead to changes in the species that grow in the study area. Drought-tolerant species could replace other species, while continuous preferential grazing of grass species may result in the spread of less favorable plant species that are not eaten by the livestock, and therefore considered a negative change $[73,74]$. The Masai herders in the study did complain about the lower quality and less availability of grass resources in the area, and mentioned drought and high livestock numbers as the main causes for the decline [24,25].

\section{Conclusions}

This study used remote-sensing-based datasets of meteorology and vegetation cover to analyze vegetation resilience in the Monduli and Longido districts of North Tanzania. The results of meteorological analysis show that the amounts of rainfall in the Monduli and Longido districts did not change significantly during the study period (1940-2020), but that temperatures increased by $1.06^{\circ} \mathrm{C}$ over the same period. The rising temperature resulted in higher potential evapotranspiration rates, which significantly increased drought occurrence and frequency. Since the early 1990s serious droughts became more frequent as well as longer, and it can be expected that in the future this trend will continue, given the climate projections for Tanzania.

Vegetation cover in the two districts declined significantly by $9.7 \%$ over the period of 1981-2020. This decline in cover could be due to several reasons, but the increase in drought most likely played an important role. Other reasons such as overgrazing by livestock, land use conversions and species changes may have played a role as well, which have all been indicated to occur according to local Masai herders. Despite the overall decline in vegetation cover and more severe drought conditions, the resilience of the vegetation was high. A drought year or season affected vegetation cover and health, as indicated by lower NDVI values, but the vegetation recovered quickly during the following rainy season when the amounts of rainfall were back to normal or above-normal levels.

Finally, it is concluded that despite the overall decline in vegetation cover, the changes have not been as dramatic as earlier reported, and vegetation resilience is still good in the study area. The climate change predictions for the area suggest a higher occurrence of drought, which could cause a further decline in vegetation cover. In addition, a shift in vegetation species to more drought-prone species could occur, which may lead to fewer grazing resources for the local Masai herdsmen.

Author Contributions: Conceptualization, S.L.V. and G.S.; methodology, S.L.V., T.K. and G.S.; formal analysis, S.L.V. and T.K.; resources, S.L.V., T.K., R.K. and J.W.; writing-original draft preparation, S.L.V., T.K. and G.S.; writing-review and editing, S.L.V., T.K., R.K., J.W. and G.S.; visualization, S.L.V. and T.K.; supervision, G.S. All authors have read and agreed to the published version of the manuscript.

Funding: This research received no external funding.

Institutional Review Board Statement: Not applicable.

Informed Consent Statement: Not applicable.

Data Availability Statement: The data presented in this study are openly available on GitHub/Zenodo at https:/ / doi.org/10.5281/zenodo.4635298 accessed on 21 October 2021.

Conflicts of Interest: The authors declare no conflict of interest.

\section{References}

1. Zhu, Z.; Piao, S.; Myneni, R.B.; Huang, M.; Zeng, Z.; Canadell, J.G.; Ciais, P.; Sitch, S.; Friedlingstein, P.; Arneth, A.; et al. Greening of the Earth and its drivers. Nat. Clim. Chang. 2016, 6, 791-795. [CrossRef]

2. Newbold, T.; Hudson, L.N.; Hill, S.L.L.; Contu, S.; Lysenko, I.; Senior, R.A.; Börger, L.; Bennett, D.J.; Choimes, A.; Collen, B.; et al. Global effects of land use on local terrestrial biodiversity. Nature 2015, 520, 45-50. [CrossRef] 
3. Kiunsi, R.B.; Meadows, M.E. Assessing land degradation in the Monduli District, northern Tanzania. Land Degrad. Dev. 2006, 17, 509-525. [CrossRef]

4. IPBES. The IPBES Assessment Report on Land Degradation and Restoration; Montanarella, L., Scholes, R., Brainich, A., Eds.; Secretariat of the Intergovernmental Science-Policy Platform on Biodiversity and Ecosystem Services: Bonn, Germany, 2018. [CrossRef]

5. Tangud, T.; Nasahara, K.; Borjigin, H.; Bagan, H. Land-cover change in the Wulagai grassland, Inner Mongolia of China between 1986 and 2014 analysed using multi-temporal Landsat images. Geocarto Int. 2018, 6049, 1-15. [CrossRef]

6. Pullanikkatil, D.; Palamuleni, L.G.; Ruhiiga, T.M. Land use/land cover change and implications for ecosystems services in the Likangala River Catchment, Malawi. Phys. Chem. Earth 2016, 93, 96-103. [CrossRef]

7. Wickama, J.; Okoba, B.; Sterk, G. Effectiveness of sustainable land management measures in West Usambara highlands, Tanzania. Catena 2014, 118, 91-102. [CrossRef]

8. Millenium Ecosystem Assessment. Ecosystems and Human Well-Being, Synthesis; Island Press: Washington, DC, USA, 2005.

9. United Nations. Convention to Combat Desertification in Those Countries Experiencing Serious Drought and/or Desertification, Particularly in Africa; Paris, 14 October 1994; United Nations Treaty Series; United Nations: Paris, France, 1994; Volume 1954, p. 3. Available online: https://treaties.un.org/doc/Publication/MTDSG/Volume\%20II/Chapter\%20XXVII/XXVII-10.en.pdf (accessed on 21 October 2021).

10. Tal, A.; Cohen, J.A. Bringing Top-down to Bottom-up: A New Role for Environemtal Legislation in Combating Desertification. Harv. Environ. Law Rev. 2007, 31, 163-271.

11. Sheffield, J.; Wood, E.F. Projected changes in drought occurrence under future global warming from multi-model, multi-scenario, IPCC AR4 simulations. Clim. Dyn. 2008, 31, 79-105. [CrossRef]

12. Trenberth, K.E.; Dai, A.; van der Schrier, G.; Jones, P.D.; Barichivich, J.; Briffa, K.R.; Sheffield, J. Global warming and changes in drought. Nat. Clim. Chang. 2014, 4, 17-22. [CrossRef]

13. Churkina, G.; Running, S.W. Contrasting Climatic Controls on the Estimated Productivity of Global Terrestrial Biomes. Ecosystems 1998, 1, 206-215. [CrossRef]

14. Drought Risk Reduction Framework and Practices: Contributing to the Implementation of the Hyogo Framework for Action; UN Office for Disaster Risk Reduction: Geneva, Switzerland, 2009.

15. Busby, J.W.; Smith, T.G.; Krishnan, N. Climate security vulnerability in Africa mapping 3.01. Polit. Geogr. 2014, 43, 51-67. [CrossRef]

16. Landmann, T.; Dubovyk, O. Spatial analysis of human-induced vegetation productivity decline over eastern Africa using a decade (2001-2011) of medium resolution MODIS time-series data. Int. J. Appl. Earth Obs. Geoinf. 2014, 33, 76-82. [CrossRef]

17. Wei, F.; Wang, S.; Fu, B.; Pan, N.; Feng, X.; Zhao, W.; Wang, C. Vegetation dynamic trends and the main drivers detected using the ensemble empirical mode decomposition method in East Africa. Land Degrad. Dev. 2018, 29, 2542-2553. [CrossRef]

18. De Jong, R.; Verbesselt, J.; Zeileis, A.; Schaepman, M.E. Shifts in global vegetation activity trends. Remote Sens. 2013, 5, 1117-1133. [CrossRef]

19. Wei, F.; Wang, S.; Fu, B.; Wang, L.; Liu, Y.Y.; Li, Y. African dryland ecosystem changes controlled by soil water. Land Degrad. Dev. 2019, 30, 1564-1573. [CrossRef]

20. Vicente-Serrano, S.M.; Gouveia, C.; Camarero, J.J.; Begueria, S.; Trigo, R.; Lopez-Moreno, J.I.; Azorin-Molina, C.; Pasho, E.; Lorenzo-Lacruz, J.; Revuelto, J.; et al. Response of vegetation to drought time-scales across global land biomes. Proc. Natl. Acad. Sci. USA 2013, 110, 52-57. [CrossRef]

21. Sterk, G.; Stoorvogel, J.J. Desertification-Scientific Versus Political Realities. Land 2020, 9, 156. [CrossRef]

22. Keijzer, T. Drought Analysis of the Lake Manyara Catchment: Meteorological Drought Occurence, Influence of Atmospheric Teleconnections and Impact on Lake Manyara. Master's Thesis, Utrecht University, Utrecht, The Netherlands, 2020.

23. Wynants, M.; Solomon, H.; Ndakidemi, P.; Blake, W.H. Pinpointing areas of increased soil erosion risk following land cover change in the Lake Manyara catchment, Tanzania. Int. J. Appl. Earth Obs. Geoinf. 2018, 71, 1-8. [CrossRef]

24. Verhoeve, S.L. Satellite Based Analysis of Environmental Changes in the Monduli and Longido Districts, Tanzania. Master's Thesis, Utrecht University, Utrecht, The Netherlands, 2019.

25. Van Den Bergh, H.A.J. The Impacts of Maasai Settlements on Land Cover, Meteorological Conditions and Wind Erosion Risk in Northern Tanzania. Master's Thesis, Utrecht University, Utrecht, The Netherlands, 2016.

26. Blake, W.H.; Rabinovich, A.; Wynants, M.; Kelly, C.; Nasseri, M.; Ngondya, I.; Patrick, A.; Mtei, K.; Munishi, L.; Boeckx, P.; et al. Soil erosion in East Africa: An interdisciplinary approach to realising pastoral land management change. Environ. Res. Lett. 2018, 13, 124014. [CrossRef]

27. UN OCHA ROSA Tanzania Administrative Level 0-3 Boundaries. Available online: https://data.humdata.org/dataset/tanzaniaadministrative-boundaries-level-1-to-3-regions-districts-and-wards-with-2012-population (accessed on 11 December 2018).

28. National Bureau of Statistics. 2012 Population and Housing Census; Ministry of Finance: Dar es Salaam, Tanzania, 2013.

29. Deus, D.; Gloaguen, R.; Krause, P. Water balance modeling in a semi-arid environment with limited in situ data using remote sensing in lake manyara, east african rift, tanzania. Remote Sens. 2013, 5, 1651-1680. [CrossRef]

30. Prins, H.H.T. Nature conservation as an integral part of optimal land use in East Africa: The case of the Masai ecosystem of Northern Tanzania. Biol. Conserv. 1987, 40, 141-161. [CrossRef]

31. Quénéhervé, G.; Bachofer, F.; Maerker, M. Experimental assessment of runoff generation processes on hillslope scale in a semiarid region in Northern Tanzania. Geogr. Fis. Din. Quat. 2015, 38, 55-66. [CrossRef] 
32. Conroy, A.B. Maasai Oxen, Agriculture and Land Use Change in Monduli District, Tanzania; University of New Hampshire: Durham, NH, USA, 2001.

33. Tanzania Meteorological Authority, Daily Rainfall Data, Monthly Rainfall Data, Monthly Temperature Data; Retrieved through personal communication; Tanzania Meteorology Agency: Arusha, Tanzania, 2019.

34. Butz, R.J. Traditional fire management: Historical fire regimes and land use change in pastoral East Africa. Int. J. Wildl. Fire 2009, 18, 442-450. [CrossRef]

35. Salvatori, V.; Egunyu, F.; Skidmore, A.K.; De Leeuw, J.; Van Gils, H.A.M. The effects of fire and grazing pressure on vegetation cover and small mammal populations in the Maasai Mara National Reserve. Afr. J. Ecol. 2001, 39, 200-204. [CrossRef]

36. Lillesand, T.; Kiefer, R.W.; Chipman, J. Remote Sensing and Image Interpretation; John Wiley \& Sons: Hoboken, NJ, USA, 2015; ISBN 111834328X.

37. Lanorte, A.; Manzi, T.; Nolè, G.; Lasaponara, R. On the Use of the Principal Component Analysis (PCA) for Evaluating Vegetation Anomalies from LANDSAT-TM NDVI Temporal Series in the Basilicata Region (Italy). In International Conference on Computational Science and Its Applications; Gervasi, O., Murgante, B., Misra, S., Gavrilova, M.L., Rocha, A.M.A.C., Torre, C., Taniar, D., Apduhan, B.O., Eds.; Springer International Publishing: Cham, Switzerland, 2015; pp. 204-216.

38. Hawinkel, P.; Thiery, W.; Lhermitte, S.; Swinnen, E.; Verbist, B.; Van Orshoven, J.; Muys, B. Vegetation response to precipitation variability in East Africa controlled by biogeographical factors. J. Geophys. Res. Biogeosciences 2016, 121, 2422-2444. [CrossRef]

39. Vermote, E. NOAA CDR Program NOAA Climate Data Record (CDR) of AVHRR Normalized Difference Vegetation Index (NDVI), Version 5. Available online: https:// doi.org/10.7289/V5ZG6QH9 (accessed on 22 September 2020). [CrossRef]

40. Gorelick, N.; Hancher, M.; Dixon, M.; Ilyushchenko, S.; Thau, D.; Moore, R. Google Earth Engine: Planetary-scale geospatial analysis for everyone. Remote Sens. Environ. 2017, 202, 18-27. [CrossRef]

41. Rojas, O.; Vrieling, A.; Rembold, F. Assessing drought probability for agricultural areas in Africa with coarse resolution remote sensing imagery. Remote Sens. Environ. 2011, 115, 343-352. [CrossRef]

42. Tucker, C.J.; Pinzon, J.E.; Brown, M.E.; Slayback, D.A.; Pak, E.W.; Mahoney, R.; Vermote, E.F.; El Saleous, N. An extended AVHRR 8-km NDVI dataset compatible with MODIS and SPOT vegetation NDVI data. Int. J. Remote Sens. 2005, 26, 4485-4498. [CrossRef]

43. Funk, C.; Nicholson, S.E.; Landsfeld, M.; Klotter, D.; Peterson, P.; Harrison, L. The Centennial Trends Greater Horn of Africa precipitation dataset. Sci. Data 2015, 2, 150050. [CrossRef]

44. Funk, C.; Peterson, P.; Landsfeld, M.; Pedreros, D.; Verdin, J.; Shukla, S.; Husak, G.; Rowland, J.; Harrison, L.; Hoell, A.; et al. The climate hazards infrared precipitation with stations-A new environmental record for monitoring extremes. Sci. Data 2015, 2, 150066. [CrossRef]

45. Harris, I.; Osborn, T.J.; Jones, P.; Lister, D. Version 4 of the CRU TS monthly high-resolution gridded multivariate climate dataset. Sci. Data 2020, 7, 1-18. [CrossRef]

46. Moulin, S.; Kergoat, L.; Viovy, N.; Dedieu, G. Global-Scale Assessment of Vegetation Phenology Using NOAA/AVHRR Satellite Measurements. J. Clim. 1997, 10, 1154-1170. [CrossRef]

47. Chamaille-Jammes, S.; Fritz, H.; Murindagomo, F. Spatial patterns of the NDVI-rainfall relationship at the seasonal and interannual time scales in an African savanna. Int. J. Remote Sens. 2006, 27, 5185-5200. [CrossRef]

48. Forkel, M.; Carvalhais, N.; Verbesselt, J.; Mahecha, M.D.; Neigh, C.S.R.; Reichstein, M. Trend Change Detection in NDVI Time Series: Effects of Inter-Annual Variability and Methodology. Remote Sens. 2013, 5, 2113-2144. [CrossRef]

49. Mbatha, N.; Xulu, S. Time Series Analysis of MODIS-Derived NDVI for the Hluhluwe-Imfolozi Park, South Africa: Impact of Recent Intense Drought. Climate 2018, 6, 95. [CrossRef]

50. Teferi, E.; Uhlenbrook, S.; Bewket, W. Inter-annual and seasonal trends of vegetation condition in the Upper Blue Nile (Abay) Basin: Dual-scale time series analysis. Earth Syst. Dyn. 2015, 6, 617-636. [CrossRef]

51. Sen, P.K. Estimates of the Regression Coefficient Based on Kendall's Tau. J. Am. Stat. Assoc. 1968, 63, 1379-1389. [CrossRef]

52. McKee, T.; Doesken, N.; Kleist, J. The relationship of drought frequency and duration to time scales. In Proceedings of the 8th Conference on Applied Climatology, Anaheim, CA, USA, 17-22 January 1993. [CrossRef]

53. Vicente-Serrano, S.M.; Beguería, S.; López-Moreno, J.I. A Multiscalar Drought Index Sensitive to Global Warming: The Standardized Precipitation Evapotranspiration Index. J. Clim. 2010, 23, 1696-1718. [CrossRef]

54. Thornthwaite, C.W. An Approach toward a Rational Classification of Climate. Geogr. Rev. 1948, 38, 55. [CrossRef]

55. Maggioni, V.; Massari, C. Extreme Hydroclimatic Events and Multivariate Hazards in a Changing Environment: A Remote Sensing Approach; Elsevier: Amsterdam, The Netherlands, 2019; ISBN 0128149000.

56. Masud, M.B.; Khaliq, M.N.; Wheater, H.S. Analysis of meteorological droughts for the Saskatchewan River Basin using univariate and bivariate approaches. J. Hydrol. 2015, 522, 452-466. [CrossRef]

57. Liu, Y.; Zhou, Y.; Ju, W.; Wang, S.; Wu, X.; He, M.; Zhu, G. Impacts of droughts on carbon sequestration by China's terrestrial ecosystems from 2000 to 2011. Biogeosciences 2014, 11, 2583-2599. [CrossRef]

58. Easdale, M.H.; Fariña, C.; Hara, S.; Pérez León, N.; Umaña, F.; Tittonell, P.; Bruzzone, O. Trend-cycles of vegetation dynamics as a tool for land degradation assessment and monitoring. Ecol. Indic. 2019, 107, 105545. [CrossRef]

59. Borgogno, F.; D'Odorico, P.; Laio, F.; Ridolfi, L. Effect of rainfall interannual variability on the stability and resilience of dryland plant ecosystems. Water Resour. Res. 2007, 43. [CrossRef]

60. Van Loon, A.F. Hydrological drought explained. Wiley Interdiscip. Rev. Water 2015, 2, 359-392. [CrossRef] 
61. Funk, C.; Dettinger, M.D.; Michaelsen, J.C.; Verdin, J.P.; Brown, M.E.; Barlow, M.; Hoell, A. Warming of the Indian Ocean threatens eastern and southern African food security but could be mitigated by agricultural development. Proc. Natl. Acad. Sci. USA 2008, 105, 11081-11086. [CrossRef]

62. Williams, A.P.; Funk, C. A westward extension of the warm pool leads to a westward extension of the Walker circulation, drying eastern Africa. Clim. Dyn. 2011, 37, 2417-2435. [CrossRef]

63. Lyon, B.; DeWitt, D.G. A recent and abrupt decline in the East African long rains. Geophys. Res. Lett. 2012, 39. [CrossRef]

64. Niang, I.; Ruppel, O.C.; Abdrabo, M.A.; Essel, A.; Lennard, C.; Padgham, J.; Urquhart, P. Africa. In Climate Change 2014: Impacts, Adaptation and Vulnerability. Part B: Regional Aspects. Contribution of the Working Group II to the IPCC Fifth Assessment Report; Barros, V.R., Field, C.B., Dokken, D.J., Mastrandrea, M.D., Mach, K.J., Bilir, T.E., Chatterjee, M., Ebi, K.L., Estrada, Y., Genova, R.C., Eds.; Cambridge University Press: Cambridge, UK; New York, NY, USA, 2014; pp. 1199-1265.

65. Anyah, R.O.; Qiu, W. Characteristic 20th and 21st century precipitation and temperature patterns and changes over the Greater Horn of Africa. Int. J. Climatol. 2012, 32, 347-363. [CrossRef]

66. Shongwe, M.E.; van Oldenborgh, G.J.; van den Hurk, B.; van Aalst, M. Projected Changes in Mean and Extreme Precipitation in Africa under Global Warming. Part II: East Africa. J. Clim. 2011, 24, 3718-3733. [CrossRef]

67. Nicholson, S.E. Climate and climatic variability of rainfall over eastern Africa. Rev. Geophys. 2017, 55, 590-635. [CrossRef]

68. Gebrechorkos, S.H.; Hülsmann, S.; Bernhofer, C. Analysis of climate variability and droughts in East Africa using high-resolution climate data products. Glob. Planet. Chang. 2020, 186, 103130. [CrossRef]

69. Haile, G.G.; Tang, Q.; Leng, G.; Jia, G.; Wang, J.; Cai, D.; Sun, S.; Baniya, B.; Zhang, Q. Long-term spatiotemporal variation of drought patterns over the Greater Horn of Africa. Sci. Total Environ. 2020, 704, 135299. [CrossRef] [PubMed]

70. Conway, D.; Mittal, N.; Vincent, K. Future Climate Projections for Tanzania. Available online: https:/ / www.africaportal.org/ publications / future-climate-projections-tanzania/ (accessed on 10 June 2020).

71. Kalisa, W.; Igbawua, T.; Henchiri, M.; Ali, S.; Zhang, S.; Bai, Y.; Zhang, J. Assessment of climate impact on vegetation dynamics over East Africa from 1982 to 2015. Nat. Sci. Rep. 2019, 9, 1-20. [CrossRef] [PubMed]

72. Bento, V.A.; Gouveia, C.M.; DaCamara, C.C.; Trigo, I.F. A climatological assessment of drought impact on vegetation health index. Agric. For. Meteorol. 2018, 259, 286-295. [CrossRef]

73. Herrmann, S.M.; Tappan, G.G. Vegetation impoverishment despite greening: A case study from central Senegal. J. Arid Environ. 2013, 90, 55-66. [CrossRef]

74. Van Auken, O.W. Shrub Invasions of North American Semiarid Grasslands. Annu. Rev. Ecol. Syst. 2000, 31, 197-215. [CrossRef] 